OPEN ACCESS

Edited by: Andrea Marie Feldpausch-Parker, State University of New York College of Environmental Science and

Forestry, USA

Reviewed by: Jen Schneider,

Boise State University, USA Bernhard Forchtner, University of Leicester, UK

*Correspondence: Jessica Leigh Thompson jessitho@nmu.edu

Specialty section: This article was submitted to Science and Environmental Communication,

a section of the journal Frontiers in Communication

Received: 11 May 2016 Accepted: 29 June 2016 Published: 18 July 2016

Citation:

Thompson JL, Kaiser A, Sparks EL, Shelton M, Brunden E, Cherry JA and Cebrian J (2016) Ecosystem - What? Public Understanding and Trust in Conservation Science and Ecosystem Services. Front. Commun. 1:3. doi: 10.3389/fcomm.2016.00003

\section{Ecosystem - What? Public Understanding and Trust in Conservation Science and Ecosystem Services}

\author{
Jessica Leigh Thompson ${ }^{1 *}$, Alina Kaiser ${ }^{1}$ Eric L. Sparks ${ }^{2,3}$, Michael Shelton $^{4,5}$, \\ Eric Brunden ${ }^{4,5}$, Julia A. Cherry ${ }^{6}$ and Just Cebrian ${ }^{7,8}$ \\ ${ }^{1}$ Communication and Performance Studies, Northern Michigan University, Marquette, MI, USA, ${ }^{2}$ Coastal Research and \\ Extension Center, Mississippi State University, Biloxi, MS, USA, ${ }^{3}$ Mississippi-Alabama Sea Grant Consortium, Ocean \\ Springs, MS, USA, ${ }^{4}$ Weeks Bay National Estuarine Research Reserve, Fairhope, AL, USA, ${ }^{5}$ Alabama Department of \\ Conservation and Natural Resources, Lands Division, Fairhope, AL, USA, ${ }^{6}$ Department of Biological Sciences, University of \\ Alabama - New College, Tuscaloosa, AL, USA, ${ }^{7}$ Dauphin Island Sea Laboratory, Dauphin Island, AL, USA, ${ }^{8}$ Department of \\ Marine Sciences, University of South Alabama, Mobile, AL, USA
}

In this mixed-methods study, we replicate a national Nature Conservancy survey on a regional scale to understand what local audiences know and believe about ecosystem services and conservation science. After the Deepwater Horizon oil spill in 2010, the Gulf Coast Ecosystem Restoration Council was created and charged with administering a large portion of the $\$ 13.7$ billion in penalties (via the Gulf Coast Restoration Fund) for ecosystem restoration research and implementation programs. Almost as quickly as oil gushed into the Gulf, conservation organizations (local, state, federal, and NGO) along the coast drafted proposals and requests for a piece of the funding. In December 2014, the State of Alabama submitted five proposed restoration projects with an estimated total cost of $\$ 54.2$ million. Many of the projects use the language of ecosystem science, restoration, and services to promote efforts to restore the ecosystem and economy of the Gulf Coast region. These phrases, once disciplinary jargon, are now heard in soundbites on the evening news and seen in the headlines of popular news sources (e.g., AL.com, Gulf Coast News Today, WKRG-Mobile, and WPMI-Mobile). As this phraseology becomes more pervasive in this region, our specific goal is to investigate what the public knows and believes about one of the key concepts, ecosystem services, and identify who they trust to inform them about ecosystem services. This study confirms previous evidence that the public trusts scientists, but they do not always understand the language of science.

Keywords: public understanding of science, ecosystem services, trust, conservation, ecosystem science

\section{INTRODUCTION}

Most people, outside of scientists and some policymakers, do not understand the term ecosystem services (Norgaard, 2010). To their credit, even scholars in the field continue to deliberate on a precise, shared definition of the phrase (Fisher et al., 2009; Braat and de Groot, 2012). The phrase ecosystem services has been used to describe the total economic value of the services provided by the Earth's ecological systems and the natural capital stocks (i.e., reserves of natural resources) required to support human life (e.g., forests that turn carbon dioxide into oxygen, wetlands that filter pollution 
out of stormwater run-off, etc.) (Alexander et al., 1997; Daily, 1997; Costanza et al., 1997). Regardless of the discrepancies in definition, the phrase, ecosystem services, is increasingly used in the public sphere to communicate important issues concerning the health of our local environment (e.g., Proceedings of the National Academy of Sciences special issue on ecosystem services case studies in 2008; the United Nations' Millennium Ecosystem Assessments). For example, The Nature Conservancy (TNC) (2010) has been using the term for more than a decade, but admits: "Because it is a relatively new concept for the majority of Americans and because it is a science-driven process, it can be difficult to explain without getting blank stares" [The Nature Conservancy (TNC), 2010]. In 2010, TNC commissioned a national survey (Metz and Weigal unpublished) $)^{1}$ to further investigate this gap in public understanding. The survey results indicated that only $31 \%$ of participants understood the term "ecosystem services" and believed it was a useful term (see text footnote 1). Such results are not shocking for scholars studying science communication. Many times in recent history scientific jargon has become "mainstreamed" leaving public audiences confused or left to their own interpretations of the concept (Weber and Word, 2001); this is especially pervasive with the language of climate change science (Russill and Nyssa, 2009; Somerville and Hassol, 2011).

In this case study, which is part of a larger interdisciplinary investigation, we replicated several aspects of the TNC survey at a regional scale, compiling quantitative and qualitative responses to an online and on-site version of the TNC survey. Our research goal is to understand what a group of stakeholders, who frequent natural areas along the Gulf Coast, know about ecosystem services, and who they trust to provide them with conservationrelated information. After the Deepwater Horizon oil spill in 2010, the Gulf Coast Ecosystem Restoration Council was created and charged with administering a large portion of the $\$ 13.7$ billion in penalties ( $v i a$ the Gulf Coast Restoration Fund) for ecosystem restoration research and implementation programs. Almost as quickly as oil gushed into the Gulf, conservation organizations (local, state, federal, and NGO) along the coast drafted proposals and requests for a piece of the funding. In December 2014, the State of Alabama submitted five proposed restoration projects with an estimated total cost of $\$ 54.2$ million. Many of these projects use the language of ecosystem science, restoration, and services to promote efforts to restore the ecosystem and economy of the Gulf Coast region. These phrases, once disciplinary jargon, are now heard in soundbites on the evening news and seen in the headlines of popular news sources (e.g., AL.com, Gulf Coast News Today, WKRG-Mobile, and WPMI-Mobile). As this phraseology becomes more pervasive in this region, we asked: what does the public know and believe about one of the key concepts, ecosystem services, and who do they trust to inform them about ecosystem services. This project reveals a deeper, underlying question, which we do not address here, but we challenge our readers and fellow scientists to consider: what does the concept of ecosystem

${ }^{1}$ Metz, D., and Weigel, L. (2010). Key findings from recent national opinion research on ecosystem services. Unpublished report. Available at: https://www. conservationgateway.org/Documents/Summary\%20Memo\%20Polling.pdf services offer the public? As a rather complex interdisciplinary concept, ecosystem services, presents an economic frame for valuing natural resources and the health of our local environment, which may still obscure and commodify nature (Peterson et al., 2009). Such valuations are often negotiated among experts and scientists, outside of the public's view (Menzel and Teng, 2010). Bringing the phrase into the public sphere presents tremendous opportunity as well as challenges. We encourage further thought about the potential of this concept in public deliberations about the management of natural resources.

This manuscript begins with a brief survey of recent literature on public understanding of ecosystem services. Then we explain our replication and administration of the TNC survey. We received a federal grant to administer the survey to coastal community stakeholders and visitors at one of NOAA's National Estuarine Research Reserves (NERR), the Weeks Bay NERR, on the Alabama Gulf Coast. We summarize the results and key findings from the 400 quantitative survey responses and more than 300 qualitative responses, where participants defined ecosystem services and explained their perceptions of trustworthy and not so trustworthy messengers of science and conservation information.

\section{Public Understanding of Ecosystem Services}

While the concept of ecosystem services has been discussed in scientific circles since the 1970s, it gained public attention after it was mainstreamed in the Millennium Ecosystem Assessment (de Groot et al., 2010). Since the early 2000s, efforts have increased to put the concept into practice, but public awareness about ecosystem services varies (Lewan and Söderqvist, 2002; Daily and Matson, 2008; Braat and de Groot, 2012). In 2010, TNC surveyed a representative sample of Americans on the topic of ecosystem services and assessed public understanding of the concept and phraseology. The goals of the TNC survey were to learn what people believed about the services nature provides, what people actually knew of the services nature provides and how important people believed them to be, as well as asking people to respond to different terms in lieu of ecosystem services. The results indicated that the majority of survey respondents believed that ecosystem services are very important, whether they recognize the phrase itself. For example, when asked to rate the most important benefits that nature can provide, $97 \%$ of the survey respondents believed that providing clean water and irrigation are either extremely or very important; 95\% believed that filtering water to keep it clean is extremely or very important; and $88 \%$ believed that nature providing protection from hurricanes and floods is extremely or very important (see text footnote 1). Thus, participants recognized the value in many of the common services that a healthy ecosystem can provide to a community, whether they knew they were talking about ecosystem services or not. TNC's survey is a randomized survey of the national population, seeking input on the general public's understanding of the ecosystem services concept. Very few scholars have approached public understanding of ecosystem services in this manner aside from Costanza et al. (2014) global valuation survey. More common are targeted projects assessing 
a specific audience's understanding and valuation of a local or regional ecosystem service; for example, land cover preferences in Grand County, CO, USA (Brown et al., 2012); forest, rangeland, and groundwater services in Hawaii (Daily et al., 2009); coastal outdoor recreation preferences in an Australian national park (van Riper et al., 2012); and community awareness of water and air quality in the southeastern Iberian Peninsula (Castro et al., 2011) to list a few. Numerous other case studies on public understanding and contingent valuation of specific ecosystem services exist in the literature and are worthy of reference; however, the focus of this paper is less about ecosystem valuation and more about the language and phraseology of ecosystem services.

We elaborate on a specific and relevant case study here: a group of landscape planners in the Netherlands [i.e., de Groot et al. (2010)] also investigated the struggle with the phraseology of ecosystem services. de Groot et al. (2010) elaborated on a gap in understanding between the concept of ecosystem services and the functions of an ecosystem. In their study, participants projected the term "ecosystem services" onto the concept of ecosystem functions, which led to multiple types of misunderstandings among stakeholders in a community planning project. [Note: ecosystem functions are defined as the set of ecosystem processes operating within an ecological system irrespective of whether or not such processes are useful for humans, as opposed to the definition of ecosystem services, which are the important benefits for human beings that arise from healthy functioning ecosystems, for example, production of oxygen, soil genesis, and water detoxification (de Groot, 1992; Braat and de Groot, 2012).] In this case, the stakeholders were being sent a message about ecosystem services yet they interpreted it as a message about ecosystem functions, which influenced their perception of the issue and engagement in proposed projects. This type of misunderstanding in the concept and phraseology creates a challenge for participatory community planning and collaborative conservation efforts and, as de Groot et al. (2010) contended, has led to less action on the stakeholders' part since the audience may not be able to visualize "what that [ecosystem services] means."

\section{Scientific Jargon and Non-Scientist Audiences}

Communication scholars have been studying the nuances of communicating science to the public for decades, both from the scientists' perspective [e.g., Pearson et al. (1997), Groffman et al. (2010), Besley and Nisbet (2011), Besley et al. (2012, 2016), and Besley (2014)] and from the audience's perspective [e.g., Bauer et al. (2007), Brossard and Nisbet (2007), and Ho et al. (2008, 2010)]. One of the key challenges identified throughout has been the use of scientific jargon with non-scientist audiences. Scientists regularly use scientific jargon to communicate environmental concerns, causations, and solutions, but in most cases the public does not know how to interpret scientific language (Montgomery, 2004). The communication barrier leads to the public discrediting scientific proof or being unable to decipher any meaning from it (Hassol, 2008). For example, Hassol (2008) used public survey data to explain different interpretations of scientific terminology:
PDF is a probability density function to scientists, but to the public it's the portable document format. THC means thermohaline circulation to scientists, but it's the active ingredient in marijuana to those members of the public who would recognize it at all (Hassol, 2008, p. 106).

Hassol also explained that for much of the public, the word "ecology" means environmentalism rather than a scientific discipline and "discipline" is about "keeping children in line" rather than a field of study. Other examples in Hassol's (2008) analysis include: "organic" which means "grown without chemicals" rather than carbon-based life forms; "nutrients" are always a good thing, as is "enrichment"; and "exotic" generally "has positive connotations."

Despite jargon and differences in meaning, the public generally trusts scientists (Pew Research Center, 2009; Retzbach and Maier, 2014); in fact, data from the General Social Survey demonstrate that confidence in scientists has been relatively stable since 1973 (Smith and Son, 2013). The GSS data also show that 95\% of surveyed individuals agree that scientists are "helping to solve challenging problems," and $88 \%$ agreed that scientists are "dedicated people who work for the good of humanity." The public's trust of experts has been shown to play an influential role in shaping peoples' views about numerous environmental issues, especially the most heavily investigated issue, climate change. For example, Malka et al. (2009) found that for people who trust scientific information, increased knowledge about climate change was associated with increased concern. Campbell (2011) compared three science communication contexts and found that scientists communicating with the public needed to deliberately develop their message with knowledge of their audience. Campbell suggests that scientists, who are perceived as trusted experts, should avoid depending upon traditional news media and public authorities to carry the message, and they should instead work independently to develop multi-media messages in alternative forums. On the other hand, Rabinovich et al. (2012) demonstrated that audience's expectations regarding how scientists should communicate can influence the extent that their messages increase people's willingness to take action. In this study, people who expected scientists to use persuasion were more receptive to persuasion, but the opposite was true for those who believe scientists' role is simply to inform.

\section{Research Questions}

Previous research indicates that lay audiences of local citizens have little if any understanding of ecosystem services and that they (the public) typically trust scientists when it comes to communicating complex environmental or conservation issues. In this study, we investigate whether or not the national trends prevail in a region where this phraseology, science, and politics are broadcast daily. Essentially, we have conducted in-depth target audience research to determine how best to inform the public and promote an ecosystem services approach to wetland restoration along the Gulf Coast. We propose two research questions related to investigating the audience's knowledge about ecosystem services and preferred sources for trustworthy information about conservationrelated issues: 
RQ 1: what do coastal community stakeholders already know about ecosystem services and related conservation and restoration efforts?

RQ 2: who is a trustworthy messenger for coastal community stakeholders, and why?

\section{METHODOLOGY}

To answer these questions, we designed and administered a nonrandom target audience survey. The survey was modeled after TNC's 2010 and 2012 public opinion poll about the phraseology of ecosystem services (Metz and Weigel, unpublished) ${ }^{2}$ because it was a previously vetted tool that demonstrated reliability in assessing public audience's awareness, understanding, and attitudes toward the concept of ecosystem services, not the valuation of specific regional ecosystem functions or services. In the summer of 2013, we distributed the survey via the "friends mailing list" and members of the coastal stakeholder group responded to the online version of the survey $(n=201)$. In the summer of 2014, we administered the survey face-to-face at specific locations within a 25-mile radius of the Weeks Bay National Estuarine Research Reserve $(n=226)$ along the Gulf Coast. The survey questions were an attempt to quantify respondents' awareness and attitudes about conservation and ecosystem services. Our audience consisted of, but was not limited to, visitors, fishers, boaters, volunteers, and members of the Weeks Bay NERR and Foundation, which included a team of highly engaged stakeholders involved in developing conservation scenarios and decision-making tools in this region.

\section{Survey Administration}

We reached the online respondents by e-mailing directly, posting the survey on the Weeks Bay Facebook page, and making

${ }^{2}$ Metz, D., and Weigel, L. (2013). The language of conservation 2013: the updated recommendations on how to communicate effectively to build support for conservation. Unpublished report provided by Public Opinion Strategies. Available at: http://www.elkhornsloughctp.org/uploads/files/13824621782013\%20 Language $\% 20$ of\%20Conservation\%20Memo.pdf the survey available on iPads at the Week Bay's visitor center. One week after the survey launched, a reminder e-mail was sent. A total of 201 surveys were completed between July 10, 2013 and August 20, 2013. In June 2014, we administered the survey using an on-site intercept approach. Over the course of a month (June 1 -June 28, 2014), a student researcher approached every visitor, fisher, boater, and volunteer at a dozen different locations within a 25-mile radius of the Weeks Bay Reserve, focusing on the most heavily visited areas. Using an intercept approach, she invited every person she saw to participate in the survey. The response rate varied by day, but on average she attained a slightly more than $70 \%$ response rate, which is typical for on-site surveys (Hox and de Leeuw, 1994; Krosnick, 1999), whereas online surveys typically only garner $21-30 \%$ response rates (Sheehan, 2001; Kaplowitz et al., 2005).

\section{Survey Respondents}

The survey respondents $(n=427)$ ranged in age from 12 to 82; $50 \%$ were male and a majority (69\%) described themselves as Caucasian. Seventy eight percent of respondents lived in the Gulf State region and 58\% were from Alabama. More than 60\% have earned a 4-year college degree or graduate degree. There was an obvious difference in the gender, environmental concern, and information seeking behaviors between the two survey administration groups (see Table 1).

\section{Knowledge about Conservation and Ecosystem Services}

In 2013, 35\% of our respondents felt they knew enough information about the following terms to be able to tell others: ecosystem services, ecosystem functions, nutrient pollution, eutrophication, and stormwater pollution. In 2014, the response was much different; $<10 \%$ reported being familiar with the terms: ecosystem services, ecosystem functions, nutrient pollution, and eutrophication, although $20 \%$ were very familiar with the term stormwater pollution. Twenty-eight percent of respondents said they had never heard the term ecosystem services, but most ( $88 \%$ in 2014 ; $80 \%$ in 2013) agreed that the indirect benefits nature provides and restoring marshlands is very or extremely important.

TABLE 1 | Demographic differences between the 2013 and 2014 survey respondents.

\begin{tabular}{|c|c|c|c|}
\hline & 2013 respondents (online), $n=201$ & 2014 respondents (on-site), $n=226$ & Combined responses, $n=427$ \\
\hline Age & 18-77; average 43 & 12-82; average 45 & 12-82; average 44 \\
\hline Gender & $\begin{array}{l}65 \% \text { female } \\
35 \% \text { male }\end{array}$ & $\begin{array}{l}37 \% \text { female } \\
63 \% \text { male }\end{array}$ & $\begin{array}{l}50 \% \text { female } \\
50 \% \text { male }\end{array}$ \\
\hline Education & $\begin{array}{l}32 \% \text { have a graduate degree } \\
19 \% \text { have a college degree }\end{array}$ & $\begin{array}{l}15 \% \text { have a graduate degree } \\
25 \% \text { have a college degree }\end{array}$ & $60 \%$ have a college or graduate degree \\
\hline $\begin{array}{l}\text { Interest in environmental } \\
\text { issues }\end{array}$ & $\begin{array}{l}58 \% \text { extremely interested } \\
27 \% \text { very interested }\end{array}$ & $\begin{array}{l}29 \% \text { extremely interested } \\
40 \% \text { very interested }\end{array}$ & $76 \%$ very or extremely interested \\
\hline $\begin{array}{l}\text { Regularly seek information } \\
\text { about the environment }\end{array}$ & $\begin{array}{l}63 \% \text { seek information once a week } \\
\text { or more }\end{array}$ & $20 \%$ seek information once a week or more & $40 \%$ frequently seek information \\
\hline Concern about environment & $\begin{array}{l}60 \% \text { extremely concerned } \\
29 \% \text { very concerned }\end{array}$ & $\begin{array}{l}37 \% \text { extremely concerned } \\
39 \% \text { very concerned }\end{array}$ & $82 \%$ are very or extremely concerned \\
\hline Regularly visit natural areas & $58 \%$ visit once a week or more & $57 \%$ visit once a week or more & $57 \%$ visit a natural area once a week or more \\
\hline
\end{tabular}


To complement the self-report of knowledge, we asked participants to define ecosystem services "in their own words." Three hundred and seven respondents provided an answer to this question. Using an open coding approach, three coders, working independently (intercoder reliability score: 97\%), identified four main categories of responses: (1) a correct definition; (2) a definition that emphasized an environmental "service" provided by or purchased by an agency; (3) a definition characterizing a group or agency that takes care of ecosystems/provides environmental protection; or (4) a self-admitting "I don't know" or "I have no clue!"

Figure 1 illustrates the categorization of the 307 responses. Sixty three percent of the online survey respondents provided a correct answer, while $<1 \%$ of the on-site respondents defined ecosystem services accurately. We can only assume that the online survey respondents were able to access information resources on the World Wide Web, since several responses matched the Wikipedia definition precisely (i.e., a copy-and-paste survey response). Those who answered incorrectly provided several interesting responses, many of which were thoughtful guesses based on their pre-existing definitions of ecosystems and services. Nearly a quarter $(23 \%)$ of respondents defined ecosystem services as some type of service provided by an agency or the government to maintain ecosystems. For example: "[Ecosystem services are] services provided by public and private sectors that contribute to the overall well being of our environment." Another respondent defined ecosystem services as: "Services that are performed to protect the ecosystem, like the EPA, which goes way too far." Many participants reported that they believed ecosystem services are something that must be paid for, and included a negative connotation in their definition of ecosystem services and environmental organizations that advocate for ecosystem services.

We get a sense of what phraseology might work in looking at the unique accurate responses (not the copy-and-paste Wikipedia answers). For example:

How our wetlands preserve our plant, animal and insect population that in turn preserve us," and "Services in nature that interact with the air, ground and water to provide the system that is vital for both animals and humans to survive.

While these responses may not be textbook answers, they demonstrate an awareness that the environment is functioning in ways that benefit those living in and around it and have a larger impact globally. Additionally, examples of responses with a mostly correct understanding of ecosystem services include some aspect of systems understanding, but lack the critical understanding of humans benefiting: "Resources or functions supplied by or performed by an ecosystem," and "how the ecosystem supports a healthy environment by filtering toxins."

More than a third of respondents who had at least some understanding of the term ecosystem services used the term benefits to define ecosystem services in their own words and commonly defined it as: "benefits to humans provided by the ecosystem." Another reoccurring term used, although not as common as

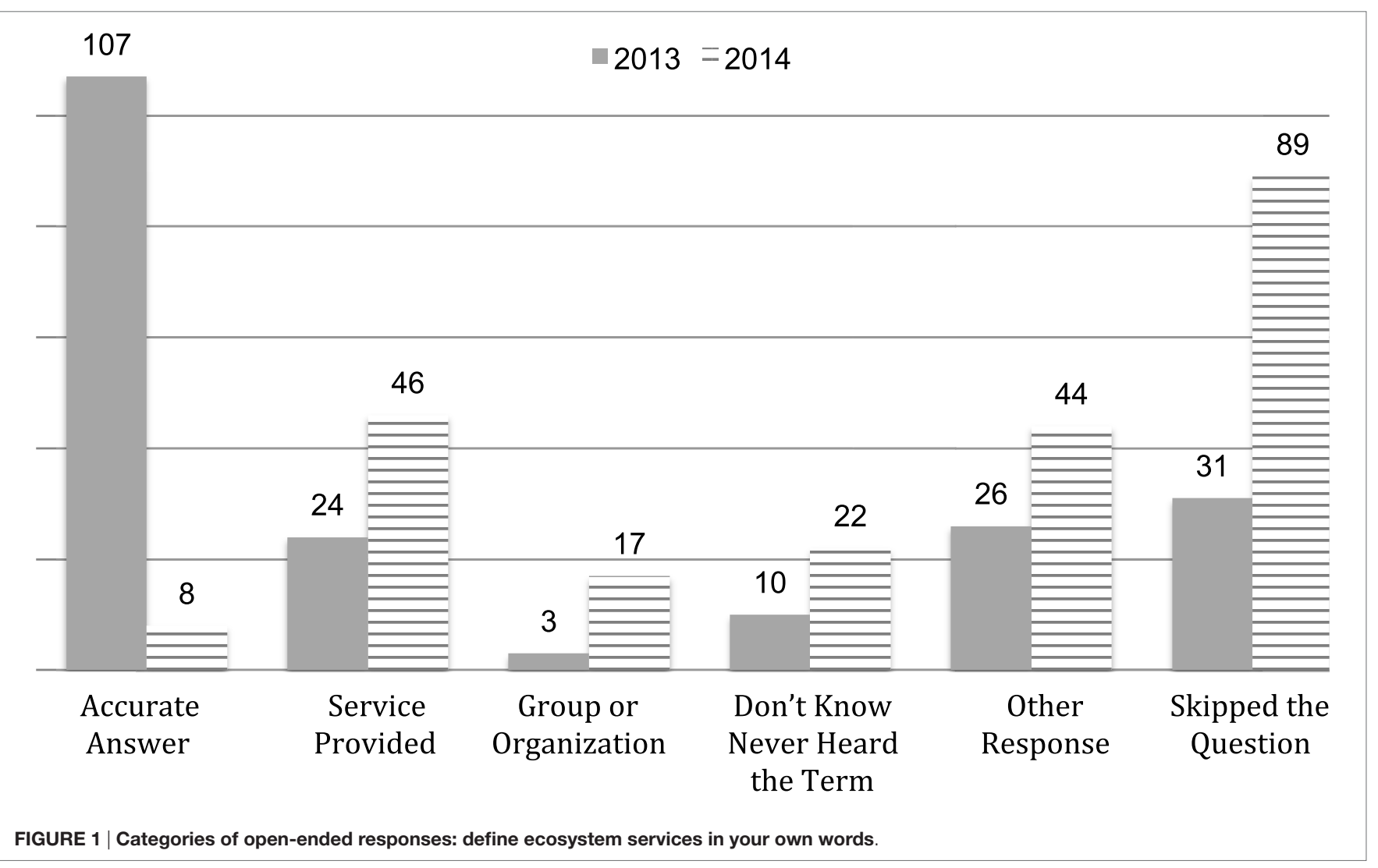


benefit, was value. A number of responses defined ecosystem services to be a variation of "services provided by the ecosystem that have some value to humans, monetary or otherwise," again showing the understanding of ecosystem services and its relationship to human benefit.

Also, in examining the responses from the participants who understood the term well, we see a combined understanding of humans and system dynamics:

A function or resource of the ecosystem that provides some tangible benefit to us, the people," and "the benefits that humans derive from a functioning ecosystem: clean air and water, flood reduction and storm buffering and the things we extract directly from the system such as food, industrial products and medicine.

These responses show an understanding of both the functions ecosystems provide and recognize the functions as services to humans based on the benefits we receive from a healthy ecosystem. Using the language of our "accurate audience member definitions" may be a useful tool for communicating with the larger target audience (e.g., using "plain language" instead of scientific jargon) about the benefits of wetland restoration and ecosystem services on the Gulf Coast.

\section{Trustworthy Messengers}

The second part of our investigation was to identify trustworthy sources of conservation information for our target audience. Decades of communication and social psychology research has explored the role of trust in lay audiences' understanding of science and public health messages [e.g., Petty and Wegener (1998), Pornpitakpan (2004), Wynne (2006), and National Science Board (2012)]. Research suggests that trust not only influences the audience's understanding of a message, but the "validity" that they assign to that message (Malka et al., 2009). Additionally, communication credibility literature is replete with evidence that audiences tend to trust (or more highly rate as trustworthy) people who are perceived as being similar to them (Brewer and Brown, 1998) or competent experts (Fiske and Dupree, 2014) with a trustworthy institutional affiliation (Priest, 2001).
So, who do coastal community stakeholders trust to inform them about ecosystems services? We provided survey participants with the same list of messengers used in the TNC survey (see Table 2) and asked: "Please rate how trustworthy the following sources are for you, when used to explain ecosystem services and conservation."

Scientists have long been recognized as "expert" messengers, but rarely are they rated as the most trustworthy communicators (Fiske and Dupree, 2014). For the coastal community audience surveyed here, there may be a unique nuance to this high rating because of the history of environmental devastation and restoration in the Gulf Coast region. Beyond scientists, the 2013 audience preferred professors to hunters and fishers, whereas the 2014 respondents rated hunters and fishers as the second most trustworthy source, again, this shift may be directly related to the difference in demographics between the online and on-site survey respondents. Both sets of respondents rated conservation organizations (ranked third) and state department of natural resources (ranked fourth) much higher than the national sample of TNC survey respondents.

In open-ended responses, many respondents clarified that scientists are trustworthy because they are "less likely to have a hidden agenda" or "financial motive," which echoes prior research [e.g., Pielke (2007) and Pew Research Center (2009, 2015)]. Among our respondents who rated scientists as very trustworthy, it was because they believed that scientists are the most concerned about using science to improve the health and management of the ecosystem. These respondents explained that those who are educated or specialize in environmental knowledge are most credible; for example: "they have firsthand knowledge and experience in the subject, deal in facts and have no profit motive or ideological reason to distort the truth."

Respondents also explained why other sources were less trustworthy, and as expected, regional companies and the state chamber of commerce were characterized as not having expertise relevant to ecosystem science. For example, "Sources that are less trustworthy are those groups that either have no scientific background or experience with natural resources and those whose main goal has an economic bottom line that can be in conflict with the conservation priorities." In the explanations

TABLE 2 | Trustworthy ratings of potential messengers to explain ecosystem services.

\begin{tabular}{|c|c|c|c|c|}
\hline $\begin{array}{l}\text { Potential messengers }(0=\text { not at all trustworthy; } 4=\text { very } \\
\text { trustworthy) }\end{array}$ & $\begin{array}{l}2013 \text { trustworthiness } \\
\text { rating }\end{array}$ & $\begin{array}{l}2014 \text { trustworthiness } \\
\text { rating }\end{array}$ & $\begin{array}{l}\text { Average trustworthiness } \\
\text { rating }\end{array}$ & $\begin{array}{l}\text { Trustworthiness } \\
\text { ranking }\end{array}$ \\
\hline Scientists & 3.31 & 3.05 & 3.18 & 1 \\
\hline Professors at a major research university & 3.26 & 2.93 & 3.1 & 2 \\
\hline Conservation organizations & 3.08 & 2.97 & 3.03 & 3 \\
\hline Professors at a local university & 3.18 & 2.88 & 3.03 & 3 \\
\hline Your state department of natural resources & 2.78 & 2.76 & 2.77 & 4 \\
\hline Hunters and fishers & 2.51 & 2.97 & 2.74 & 5 \\
\hline Federal land management agencies (e.g., USFWS, USFS, NPS) & 2.83 & 2.58 & 2.71 & 6 \\
\hline Farmers and ranchers & 2.37 & 2.90 & 2.64 & 7 \\
\hline Doctors and nurses & 2.11 & 2.49 & 2.3 & 8 \\
\hline Private land owners & 2.05 & 2.51 & 2.28 & 9 \\
\hline Local small business owners & 1.97 & 2.45 & 2.21 & 10 \\
\hline Your state chamber of commerce & 1.66 & 2.23 & 1.95 & 11 \\
\hline Regional companies & 1.58 & 2.06 & 1.82 & 12 \\
\hline
\end{tabular}


used to describe why these entities are not trustworthy, many respondents used words such as bias, money, and agenda to describe why private landowners, business owners, regional companies, and the state chamber of commerce are less trustworthy.

\section{APPLICATIONS AND RECOMMENDATIONS}

The Gulf Coast region may experience tremendous environmental change in the next decade from multiple multi-million dollar restoration projects coupled with the increasing impacts of climate change; citizens in this region are going to be inundated with scientific jargon whether they are prepared or not. Studying this region now provides a snapshot for comparison in the future, but it also provides a rich and nuanced opportunity to investigate public understanding of complex environmental science and terminology. Based on our findings, we would argue that stakeholders in this region need plain language from plain-clothed people, which reiterates the principles of Olson's work (Olson, 2009, 2015; Olson et al., 2013). While they trust experts in uniform, they also trust scientists and appreciate when scientists communicate in ways that are similar to "people like me." They also seem to prefer to talk about the benefits nature can provide, instead of the destruction humans cause. Thus, we propose two key recommendations for this region: (1) scientists should continue to actively participate and communicate in the public sphere and (2) they should continue to be creative in their explanation of key concepts relevant to ecosystem restoration and ecosystem services in the region. In many ways, typical science communicators suffer from the "curse of knowledge" (Heath and Heath, 2007), meaning that they cannot quite remember (or communicate) what it was like to not know what they know. For this region, science communicators have a tremendous opportunity to engage stakeholders and the coastal community publics more broadly through shared science storytelling and research narratives [e.g., Olson et al. (2013), Dalhstrom (2014), and Olson (2015)]. Particular to this case, the story of ecosystem service research could be explained through local examples with local scientists detailing the questions that they are asking and how they are measuring to find answers. Providing a visual, localized narrative fits within much of the popular literature's advice for scientists communicating to a non-scientist audience [e.g., Olson $(2009,2015)$ and Olson et al. (2013)], which suggests trading jargon for visual explanations of scientific processes and phenomena.

It is important for science communicators to recognize that there are political, social, and environmental implications embedded in their public communication choices. In recent decades, it has become increasingly important for scientists to understand the average person's perception of what is being communicated about the environment (Leggett and Finlay, 2001). Understanding how non-scientists communicate increases the likelihood for productive dialog and decision-making about natural resources. Leggett and Finlay (2001) developed a visual communication system to transcend the typical communication barriers of technical jargon. They used images typically associated with energy use to initiate a discussion with study participants. By bypassing technical jargon, they were able to gain an understanding of the different depths of knowledge people have about energy use. Participants viewed images and began storytelling to communicate their knowledge regarding renewable energy. Leggett and Finlay observed what areas needed improvement in their communication and simultaneously assess what the public already knew. By side-stepping scientific jargon and using images, communicators can effectively engaged the stakeholders in productive discourse about environmental issues and conservation (Delicath and DeLuca, 2003; Nisbet, 2009; Hansen and Machin, 2013; Peeples, 2013).

Second, science messengers can make their communication creative and effective by using metaphors. By using a metaphor in environmental communication, one issue can be compared to and talked about in terms of another, more common and relatable issue (Lakoff and Johnson, 2003; Nisbet and Scheufele, 2009; Larson, 2011; Cox, 2013). Metaphors provide a mental-visual for the audience and they can be used to help the audience conceptualize scientific jargon. A metaphor to debunk the idea that climate change has always happened naturally and that humans are not adding to the problem, as Hassol (2008) illustrated, could be as simple as saying that "forest fires can often be started by lightning strikes but that is not the only cause for forest fires. A camper leaving a fire unattended could cause a forest fire making it a human-caused issue just as climate change is a human-caused issue." This metaphor is using concepts, terms, and situations that the majority of the public can understand and can use to interpret anthropogenic climate change (Hassol, 2008). Similarly, the power of metaphors can be employed by scientists to communicate about ecosystem services as Raymond et al. (2013) explored potential metaphors to explain how ecosystem services work: (1) comparing the ecosystem to an economic production model, where monetary value is provided for services rendered; (2) using Aldo Leopold's Land Ethic, a stewardship metaphor could be created to combine the economic, moral, and instrumental factors that influence conservation behavior, essentially portraying the ecosystem as "our house" or community that we live in that requires our regular upkeep; and (3) a "web-of-life" metaphor can help to identify the interdependencies among humans and other species, especially when we follow water and nutrients through the ecosystem. In any case, making connections, illustrations, and using scenarios that resonate with local audiences is bound to facilitate improved public understanding of ecosystem services and conservation, in a region that will be talking about this for the next decade or more.

\section{CONCLUSION}

Ultimately, the term ecosystem services is not common knowledge and should be handled as technical jargon would be in any other circumstance. Finding a simple explanation with a vivid metaphor will be one of the first steps in communicating the complexity of conservation issues in this region and engaging this target audience in a deeper understanding of the benefits of wetland restoration and nurtured landscapes dedicated to ecosystem services. 
While this project is only a small component to a much larger, interdisciplinary research effort, it is an important piece in understanding the local stakeholders and regional target audience. This assessment of the participants' knowledge, attitudes, and values about scientific concepts may be particularly useful in designing public conservation and outreach campaigns. Specifically, members of the coastal community target audience are interested in information about the environment; they trust scientists, but they do not understand what ecosystem services means despite the increasing pervasiveness of the phrase in the region.

\section{ETHICS STATEMENT}

Approved by the Northern Michigan University Institutional Review Board, proposal number HS14-572.

\section{REFERENCES}

Alexander, S., Ehrlich, P. R., Goulder, L., Lubchenco, J., Matson, P. A., Mooney, H. A., et al. (1997). Ecosystem Services: Benefits Supplied to Human Societies by Natural Ecosystems, Vol. 2. Washington, DC: Ecological Society of America.

Bauer, M. W., Allum, N., and Miller, S. (2007). What can we learn from 25 years of PUS survey research? Liberating and expanding the agenda. Public Underst. Sci. 16, 79-95. doi:10.1177/0963662506071287

Besley, J. C. (2014). What do scientists think about the public and does it matter to their online engagement? Sci. Public Policy 42, 201-214. doi:10.1093/scipol/ scu042

Besley, J. C., Dudo, A. D., Yuan, S., and Ghannam, N. A. (2016). Qualitative interviews with science communication trainers about communication objectives and goals. Sci. Commun. 38, 356-381. doi:10.1177/1075547016645640

Besley, J. C., and Nisbet, M. (2011). How scientists view the public, the media and the political process. Public Underst. Sci. 22, 644-659. doi:10.1177 0963662511418743

Besley, J. C., Oh, S. H., and Nisbet, M. (2012). Predicting scientists' participation in public life. Public Underst. Sci. 22, 971-987. doi:10.1177/ 0963662512459315

Braat, L. C., and de Groot, R. (2012). The ecosystem services agenda: bridging the worlds of natural science and economics, conservation and development, and public and private policy. Ecosyst. Serv. 1, 4-15. doi:10.1016/j.ecoser.2012.07.011

Brewer, M. B., and Brown, R. J. (1998). "Intergroup relations," in The Handbook of Social Psychology, 4th Edn, eds D.Gilbert, S.Fiske, and G.Lindzey (New York: McGraw-Hill), 554-595.

Brossard, D., and Nisbet, M. C. (2007). Deference to scientific authority among a low information public: understanding US opinion on agricultural biotechnology. Int. J. Public Opin. Res. 19, 24-52. doi:10.1093/ijpor/edl003

Brown, G., Montag, J. M., and Lyon, K. (2012). Public participation GIS: a method for identifying ecosystem services. Soc. Nat. Resour. 25, 633-651. doi:10.1080/ 08941920.2011.621511

Campbell, P. (2011). Understanding the receivers and the reception of science's uncertain messages. Philos. Trans. Roy. Soc. Lond. A Math. Phys. Eng. Sci. 369, 4891-4912. doi:10.1098/rsta.2011.0068

Castro, A. J., Martín-López, B., García-Llorente, M., Aguilera, P. A., López, E., and Cabello, J. (2011). Social preferences regarding the delivery of ecosystem services in a semiarid Mediterranean region. J. Arid Environ. 75, 1201-1208. doi:10.1016/j.jaridenv.2011.05.013

Costanza, R., d’Arge, R., de Groot, R., Farber, S., Grasso, M., Hannon, B., et al. (1997). The value of the world's ecosystem services and natural capital. Nature 387, 253-260. doi:10.1038/387253a0

Costanza, R., de Groot, R., Sutton, P., van der Ploeg, S., Anderson, S. J., Kubiszewski, I., et al. (2014). Changes in the global value of ecosystem services. Global Environ. Change 26, 152-158. doi:10.1016/j.gloenvcha.2014.04.002

Cox, R. (2013). Environmental Communication and the Public Sphere, 3rd Edn. Thousand Oaks, CA: SAGE, 63-65.

\section{AUTHOR CONTRIBUTIONS}

JT conceptualized study, gathered data, analyzed data, and wrote $90 \%$ of the manuscript. AK gathered data, analyzed data, and wrote $10 \%$ of the manuscript. ES assisted in conceptualizing study and assisted in gathering data, and edited manuscript. MS assisted in conceptualizing study and assisted in gathering data. EB supported study and provided access for data collection. JAC supported study and edited manuscript. JC assisted in conceptualizing study, and supported study.

\section{FUNDING}

This project was funded by the NOAA/National Estuarine Research Reserve Science Collaborative, grant \#NA09NO S4190153.

Daily, G. (1997). Nature’s Services: Societal Dependence on Natural Ecosystems. Washington, DC: Island Press.

Daily, G. C., and Matson, P. A. (2008). Ecosystem services: from theory to implementation. Proc. Natl. Acad. Sci. U.S.A. 105, 9455-9456. doi:10.1073/ pnas. 0804960105

Daily, G. C., Polasky, S., Goldstein, J., Kareiva, P. M., Mooney, H. A., Pejchar, L., et al. (2009). Ecosystem services in decision making: time to deliver. Front. Ecol. Environ. 7:25. doi:10.1890/080025

Dalhstrom, M. F. (2014). Using narratives and storytelling to communicate science with nonexpert audiences. Proc. Natl. Acad. Sci. U.S.A. 111, 12614-12620. doi:10.1073/pnas.1320645111

de Groot, R. (1992). Functions of Nature: Evaluation of Nature in Environmental Planning, Management and Decision-Making. Groningen: Wolters, Nordhoff BV.

de Groot, R. S., Alkemade, R., Braat, L., Hein, L., and Willemen, L. (2010). Challenges in integrating the concept of ecosystem services and values in landscape planning, management and decision making. Ecol. Complex. 7, 260-272. doi:10.1016/j.ecocom.2009.10.006

Delicath, J. W., and DeLuca, K. M. (2003). Image events, the public sphere, and argumentative practice: the case of radical environmental groups. Argumentation 17, 315-333. doi:10.1023/A:1025179019397

Fisher, B., Turner, R. K., and Morling, P. (2009). Defining and classifying ecosystem services for decision making. Ecol. Econ. 68, 643-653. doi:10.1016/j. ecolecon.2008.09.014

Fiske, S. T., and Dupree, C. (2014). Gaining trust as well as respect in communicating to motivated audiences about science topics. Proc. Natl. Acad. Sci. U.S.A. 111, 13593-13597. doi:10.1073/pnas.1317505111

Groffman, P. M., Stylinski, C., Nisbet, M. C., Duarte, C. M., Jordan, R., Burgin, A., et al. (2010). Restarting the conversation: challenges at the interface between ecology and society. Front. Ecol. Environ. 8:284-291. doi:10.1890/090160

Hansen, A., and Machin, D. (2013). Researching visual environmental communication. Environ. Commun. 7, 151-168. doi:10.1080/17524032.2013.785441

Hassol, S. J. (2008). Improving how scientists communicate about climate change. Eos Trans. Am. Geophys. Union 89, 106-107. doi:10.1029/2008EO110002

Heath, D., and Heath, C. (2007). Made to Stick: Why Some Ideas Survive and Others Die. New York, NY: Random House.

Ho, S. S., Brossard, D., and Scheufele, D. A. (2008). Effects of value predispositions, mass media use, and knowledge on public attitudes toward embryonic stem cell research. Int. J. Public Opin. Res. 20, 171-192. doi:10.1093/ijpor/edn017

Ho, S. S., Scheufele, D. A., and Corley, E. A. (2010). Making sense of policy choices: understanding the roles of value predispositions, mass media, and cognitive processing in public attitudes toward nanotechnology. J. Nanopart. Res. 12, 2703-2715. doi:10.1007/s11051-010-0038-8

Hox, J. J., and de Leeuw, E. D. (1994). A comparison of nonresponse in mail, telephone and face-to-face surveys. Applying multilevel modeling to meta-analysis. Qual. Quant. 28, 329-344. doi:10.1007/BF01097014

Kaplowitz, M. D., Hadlock, T. D., and Levine, R. (2005). A comparison of web and mail survey response rates. Public Opin. Q. 68, 94-101. doi:10.1093/poq/nfh006 
Krosnick, J. A. (1999). "Maximizing measurement quality: principles of good questionnaire design," in Measures of Political Attitudes, eds J. P.Robinson, P. R.Shaver, and L. S.Wrightsman (New York: Academic Press), 37-57.

Lakoff, G., and Johnson, M. (2003). Metaphors We Live By, 2nd Edn. Chicago, IL: University of Chicago Press.

Larson, B. (2011). Metaphors for Environmental Sustainability: Redefining Our Relationship with Nature. New Haven, CT: Yale University Press.

Leggett, M., and Finlay, M. (2001). Science, story and image: a new approach to crossing the communication barrier posed by scientific jargon. Public Underst. Sci. 10, 157-171. doi:10.1088/0963-6625/10/2/301

Lewan, L., and Söderqvist, T. (2002). Knowledge and recognition of ecosystem services among the general public in a drainage basin in Scania, Southern Sweden. Ecol. Econ. 42, 459-467. doi:10.1016/S0921-8009(02)00127-1

Malka, A., Krosnick, J. A., and Langer, G. (2009). The association of knowledge with concern about global warming: trusted information sources shape public thinking. Risk Anal. 29, 633-647. doi:10.1111/j.1539-6924.2009.01220.x

Menzel, S., and Teng, J. (2010). Ecosystem services as a stakeholder-driven concept for conservation science. Conserv. Biol. 24, 907. doi:10.1111/j.15231739.2009.01347.x

Montgomery, S. (2004). Of towers, walls, and fields: perspectives on language in science. Science 303, 1333-1335. doi:10.1126/science.1095204

National Science Board. (2012). "Science and technology: public attitudes and understanding," in Science and Engineering Indicators 2012 (Arlington, VA: National Science Foundation (NSB 12-01)). Available at: http://www.nsf.gov/ statistics/seind12/pdf/front.pdf

Nisbet, M. C. (2009). Communicating climate change: why frames matter for public engagement. Environment 51, 12-23. doi:10.3200/ENVT.51.2.12-23

Nisbet, M. C., and Scheufele, D. A. (2009). What's next for science communication? Promising directions and lingering distractions. Am. J. Bot. 96, 1767-1778. doi:10.3732/ajb.0900041

Norgaard, R. B. (2010). Ecosystem services: from eye-opening metaphor to complexity blinder. Ecol. Econ. 69, 1219-1227. doi:10.1016/j.ecolecon.2009.11.009

Olson, R. (2009). Don't be Such a Scientist: Talking Substance in an Age of Style. Washington, DC: Island Press.

Olson, R. (2015). Houston, We have a Narrative: Why Science Needs Story. Chicago: University of Chicago Press.

Olson, R., Barton, D., and Palermo, B. (2013). Connection: Hollywood Storytelling Meets Critical Thinking. Los Angeles, CA: Prairie Starfish Productions.

Pearson, G., Pringle, S. M., and Thomas, J. N. (1997). Scientists and the public understanding of science. Public Underst. Sci. 6, 279-289. doi:10.1088/0963$6625 / 6 / 3 / 006$

Peeples, J. (2013). Imaging toxins. Environ. Commun. 7, 191-210. doi:10.1080/17 524032.2013.775172

Peterson, M. J., Hall, D. M., Feldpausch-Parker, A. M., and Peterson, T. R. (2009). Obscuring ecosystem function with application of the ecosystem services concept. Conserv. Biol. 24, 113-119. doi:10.1111/j.1523-1739.2009.01305.x

Petty, R. E., and Wegener, D. T. (1998). "Attitude change: multiple roles for persuasion variables," in The Handbook of Social Psychology, 4th Edn, eds D.Gilbert, S.Fiske, and G.Lindzey (New York: McGraw-Hill), 323-390.

Pew Research Center. (2009). Public Praises Science: Scientists Fault Public, Media: Scientific Achievements Less Prominent than a Decade Ago. Available at: http:// www.people-press.org/files/legacy-pdf/528.pdf

Pew Research Center. (2015). Public and Scientists'Views on Science and Society. Available at: http://www.pewinternet.org/files/2015/01/PI_ScienceandSociety_ Report_012915.pdf
Pielke, R. A. (2007). The Honest Broker: Making Sense of Science in Policy and Politics. Cambridge, UK: Cambridge University Press.

Pornpitakpan, C. (2004). The persuasiveness of source credibility: a critical review of five decades' evidence. J. Appl. Soc. Psychol. 34, 243-281. doi:10.1111/ j.1559-1816.2004.tb02547.x

Priest, S. H. (2001). Misplaced faith - communication variables as predictors of encouragement for biotechnology development. Sci. Commun. 23, 97-110. doi:10.1177/1075547001023002002

Rabinovich, A., Morton, T. A., and Birney, M. E. (2012). Communicating climate science: the role of perceived communicator's motives. J. Environ. Psychol. 32, 11-18. doi:10.1016/j.jenvp.2011.09.002

Raymond, C., Singh, G., Benessaiah, K., Bernhardt, J. R., Levine, J., Nelson, H., et al. (2013). Ecosystem services and beyond: using multiple metaphors to understand human-environment relationships. Bioscience 63, 536-546. doi:10.1525/ bio.2013.63.7.7

Retzbach, A., and Maier, M. (2014). Communicating scientific uncertainty media effects on public engagement with science. Communic. Res. 42, 429-456. doi:10.1177/0093650214534967

Russill, C., and Nyssa, Z. (2009). The tipping point trend in climate change communication. Global Environ. Change 19, 336-344. doi:10.1016/j. gloenvcha.2009.04.001

Sheehan, K. B. (2001). E-mail survey response rates: a review. J. Comput. Med. Commun. 6. doi:10.1111/j.1083-6101.2001.tb00117.x

Smith, T. W., and Son, J. (2013). Trends in Public Attitudes about Confidence in Institutions. General Social Survey 2012 Final Report. NORC at the University of Chicago. Available at: http://www.norc.org/Research/Departments/Pages/ academic-research-centers/center-for-the-study-of-politics-and-society.aspx

Somerville, R. C., and Hassol, S. J. (2011). The science of climate change. Phys. Today 64, 48-53. doi:10.1063/PT.3.1296

The Nature Conservancy (TNC). (2010). Communicating Ecosystem Services. Available at: https://www.conservationgateway.org/ConservationPractices/ EcosystemServices/CommunicatingEcosystemServices/Pages/communicating-ecosystem-s.aspx

van Riper, C. J., Kyle, G. T., Sutton, S. G., Barnes, M., and Sherrouse, B. C. (2012). Mapping outdoor recreationists' perceived social values for ecosystem services at Hinchinbrook Island National Park, Australia. Appl. Geograph. 35, 164-173. doi:10.1016/j.apgeog.2012.06.008

Weber, J. R., and Word, C. S. (2001). The communication process as evaluative context: what do nonscientists hear when scientists speak? Bioscience 51, 487-495. doi:10.1641/0006-3568(2001)051[0487:TCPAEC]2.0.CO;2

Wynne, B. (2006). Public engagement as a means of restoring public trust in science - hitting the notes, but missing the music? Community Genet. 9, 211-220. doi:10.1159/000092659

Conflict of Interest Statement: The authors declare that the research was conducted in the absence of any commercial or financial relationships that could be construed as a potential conflict of interest.

Copyright (c) 2016 Thompson, Kaiser, Sparks, Shelton, Brunden, Cherry and Cebrian. This is an open-access article distributed under the terms of the Creative Commons Attribution License (CC BY). The use, distribution or reproduction in other forums is permitted, provided the original author(s) or licensor are credited and that the original publication in this journal is cited, in accordance with accepted academic practice. No use, distribution or reproduction is permitted which does not comply with these terms. 